\title{
URGENSI MENJADIKAN DESA SEBAGAI BASIS MEDIASI DALAM PENYELESAIAN SENGKETA PERDATA
}

\author{
Akhmad khalimy \\ Fakultas Syariah dan Ekonomi Islam \\ Institut Agama Islam Negeri Syekh Nurjati Cirebon \\ Email: akhalimy@gmail.com
}

\begin{abstract}
ABSTRAK
Undang-undang No 6 Tahun 2014 Tentang Desa mengamanatkan tentang perlunya pemberdayaan masyarakat desa dengan cara mengembangkan kemandirian dan kesejahteraan masyarakat dengan meningkatkan pengetahuan, sikap, keterampilan, perilaku, kemampuan, kesadaran, serta memanfaatkan sumber daya melalui penetapan kebijakan, program, kegiatan, dan pendampingan yang sesuai dengan esensi masalah dan prioritas kebutuhan masyarakat Desa.

Di satu sisi jumlah desa yang sangat besar, semakin banyak desa menjadi kota potensi konflik yang akan terus muncul di desa, ditambah dengan rendahnya tingkat pendidikan dan kemiskinan, maka pemerintah desa urgen mengenal dan menggunakan mediasi sebagai alternatif penyelesaian sengketa. Di sisi lain jumlah kasus yang masuk ke pengadilan juga terus bertambah setiap tahun.

Mengingat mediasi adalah cara penyelesaian sengketa secara damai yang tepat, efektif, dan dapat membuka akses yang lebih luas kepada Para Pihak untuk memperoleh penyelesaian yang memuaskan serta berkeadilan. Pengenalan dan penggunaan Mediasi oleh pemerintahan desa dapat dijadikan instrumen untuk meningkatkan akses masyarakat terhadap keadilan sekaligus penyelesaian sengketa secara yang sederhana, cepat, dan berbiaya ringan. Keberadaan mediasi di desa dapat memperkuat dan mengoptimalkan fungsi lembaga kemasyarakatan dalam penyelesaian sengketa; sekaligus dapat mengurangi jumlah kasus yang masuk ke pengadilan.
\end{abstract}

Kata kunci: desa, mediasi, pemberdayaan

Law No. 6 of 2014 on Villages mandates the need for empowerment of rural communities by developing the independence and welfare of the people by increasing knowledge, attitude, skills, behavior, abilities, awareness, and utilizing resources through the establishment of policies, programs, activities and assistance which corresponds to the essence of the problem and the priority needs of the village community.

On the one hand, the vast number of villages, the more villages to be a city, the conflict will continue to emerge in the village, coupled with the low level of education and poverty. It's urgent for village government recognizes and uses mediation as an alternative to dispute resolution. On the other hand, the number of cases that go to court also continues to grow every year.

Whereas mediation is a peaceful, effective, and effective way to resolve disputes, and may open broader access to the Parties for a satisfactory and just settlement. The introduction and use of Mediation by village administrations can serve as an instrument to improve people's access to justice as well as settle disputes in a simple, fast, and costly manner. The existence of village mediation can strengthen and optimize the functioning of community institutions in settlement dispute; while reducing the number of cases that go to court.

Keywords: village, mediation, empowerment 



\section{PENDAHULUAN}

\section{A. Latar Belakang}

Desa memiliki hak asal usul dan hak tradisional dalam mengatur dan mengurus kepentingan masyarakat setempat. Desa berperan dalam mewujudkan cita-cita kemerdekaan berdasarkan UndangUndang Dasar Negara Republik Indonesia Tahun 1945. Di era milenial seperti sekarang keberadaan desa telah berkembang dalam berbagai bentuk, seperti berubah menjadi kota, sehingga keberadaannya perlu dilindungi dan diberdayakan agar desa menjadi kuat, maju, mandiri, dan demokratis sehingga dapat menciptakan landasan yang kuat dalam melaksanakan pemerintahan dan pembangunan menuju masyarakat yang adil, makmur, dan sejahtera.

Saat ini menurut Mendagri total ada 83.184 jumlah desa dan kelurahan, 42.088 desa dan kelurahan yang diketahui klasifikasinya, dengan perincian 9.715 (23\%) desa dan kelurahan kurang berkembang, 24.410 (58\%) desa dan kelurahan yang berkembang serta sebanyak 7.963 (19\%) desa dan kelurahan yang cepat berkembang. ${ }^{1}$

Menurut Menteri Desa, Pembangunan Daerah Tertinggal dan Transmigrasi, Marwan Jafar, "kemiskinan, kesenjangan sosial mendorong adanya urbanisasi yang membuat desa akan ditinggalkan oleh penduduknya. Jika tahun 1980an, $78 \%$ penduduk Indonesia masih banyak yang tinggal di Desa. Tahun 2015 yang tinggal di desa sekitar

1 "Web Page," accessed March 27, 2018, http://www.kemendagri.go.id/news/2016/08/15/me ndagri-baru-42088-desa-dan-kelurahan-diketahuiklasifikasinya.
50,2\% dan diperkirakan pada tahun 2025 yang mau tinggal di desa hanya 35\% saja". ${ }^{2}$ Menteri Desa, Pembangunan Daerah Tertinggal dan Transmigrasi, Marwan Jafar, menyatakan, Sabtu (5/2/2016) bahwa jumlah penduduk miskin saat ini 28,5 juta; dengan 17,9 juta jiwa tinggal di pedesaan. ${ }^{3}$

Ketua Lembaga Demografi

Fakultas Ekonomi Universitas Indonesia Sonny Harry B Harmadi, Kamis (23/8/2012) mengatakan, meningkatnya proporsi penduduk kota dipicu oleh urbanisasi dan perubahan desa menjadi kota. Tahun 2010, dari 237 juta penduduk Indonesia 49,8\% tinggal di desa, tahun 2012 dari 240 juta penduduk Indonesia 129,7 juta (54\%) tinggal di kota. ${ }^{4}$

Di masa depan Desa semakin banyak mendapat tantangan di antaranya semakin lebarnya ketimpangan sosial dan ekonomi, peningkatan urbanisasi, perubahan desa menjadi kota. Peningkatan jumlah desa yang menjadi kota yang ditandai dengan peningkatan jumlah dan kepadatan penduduk, aktivitas ekonomi yang tidak lagi bertumpu pada pada pola pertanian tradisional dan semakin membaiknya infrastruktur.

Perubahan desa menjadi kota berakibat semakin banyaknya penduduk Indonesia yang tinggal di

2 "Web Page," accessed March 20, 2018, https://www.cnnindonesia.com/nasional/20151019 122431-20-85775/ketimpangan-tinggi-desaterancam-ditinggal-penduduk.

3 "Web Page," accessed March 20, 2018, http://nasional.republika.co.id/berita/nasional/daera h/16/02/06/o24576219-179-juta-penduduk-miskinindonesia-tinggal-di-desa.

4 "Web Page," accessed March 3, 2018, https://nasional.kompas.com/read/2012/08/23/2123 2065/

Hampir.54.Persen.Penduduk.Indonesia.Tinggal.di. Kota. 
Kota adalah tantangan yang tidak dapat dilihat semata-mata dilihat dari sisi tantangan ekonomi sosial saja tetapi harus disikapi dengan secara komprehensif dengan pendekatan multidimensi dalam rangka pemberdayaan masyarakat pedesaan dan perkotaan sekaligus.

Sebenarnya semakin banyak penduduk perkotaan, semakin baik bagi kesejahteraan masyarakat, namun banyak pemerintah kota yang tak siap dengan perubahan tersebut. Kurangnya kesiapan sumber daya manusia dan ketersediaan infrastruktur yang memadai membuat pertambahan jumlah kota dan penduduk kota menjadi tekanan sekaligus tantangan pembangunan. Jangan sampai perubahan desa menjadi kota hanya sebatas status saja tanpa ada perubahan sumber daya manusianya.

Pasal 1 ayat 12 Undangundang No: 6 Tahun 2014 Tentang Desa menyebutkan Pemberdayaan Masyarakat Desa adalah upaya mengembangkan kemandirian dan kesejahteraan masyarakat dengan meningkatkan pengetahuan, sikap, keterampilan, perilaku, kemampuan, kesadaran, serta memanfaatkan sumber daya melalui penetapan kebijakan, program, kegiatan, dan pendampingan yang sesuai dengan esensi masalah dan prioritas kebutuhan masyarakat Desa. ${ }^{5}$

Ketimpangan sosial dan ekonomi, kemiskinan dan rendahnya pendidikan dapat menjadi pemicu terjadinya konflik di dalam masyarakat, untuk itu maka

5 Sekretariat Negara RI, Undang-Undang Republik Indonesia No: 6 Tahun 2014 Tentang Desa, 2014, http://www.setneg.go.id/index.php?lang=en\&optio $\mathrm{n}=$ com_perundangan $\& \mathrm{id}=404095 \&$ task $=$ detail $\&$ cat $\mathrm{id}=1 \&$ Itemid=42\& tahun=2014. pemerintahan desa harus dijadikan basis sosialisasi pelatihan untuk mengembangkan kemandirian dan kesejahteraan masyarakat dengan meningkatkan pengetahuan, sikap, keterampilan, perilaku, kemampuan, kesadaran, serta memanfaatkan sumber daya melalui penetapan kebijakan, program, kegiatan dan pendampingan khususnya yang yang berkenaan dengan mediasi.

Sehingga jika konflik muncul di desa, maka pemerintahan desa telah mempersiapkan dirinya ataupun lembaganya untuk menyelesaikan konflik tersebut. Hal inilah yang membuat urgensi perlunya sosialisasi sekaligus pelatihan mediasi bagi pemerintahan desa.

Lebih dari pemberdayaan desa, peningkatan pengetahuan dan pelatihan mediasi di tingkat desa bisa memperkuat tujuan pengaturan desa sebagaimana tercantum dalam Pasal 4 UU tentang Desa yaitu:

a. memberikan pengakuan dan penghormatan atas Desa yang sudah ada dengan keberagamannya sebelum dan sesudah terbentuknya Negara Kesatuan Republik Indonesia;

b. memberikan kejelasan status dan kepastian hukum atas Desa dalam sistem ketatanegaraan Republik Indonesia demi mewujudkan keadilan bagi seluruh rakyat Indonesia;

c. melestarikan dan memajukan adat, tradisi, dan budaya masyarakat Desa;

d. mendorong prakarsa, gerakan, dan partisipasi masyarakat Desa untuk pengembangan potensi dan Aset Desa guna kesejahteraan bersama; 
e. membentuk Pemerintahan Desa yang profesional, efisien dan efektif, terbuka, serta bertanggung jawab;

f. meningkatkan pelayanan publik bagi warga masyarakat Desa guna mempercepat perwujudan kesejahteraan umum;

g. meningkatkan ketahanan sosial budaya masyarakat Desa guna mewujudkan masyarakat Desa yang mampu memelihara kesatuan sosial sebagai bagian dari ketahanan nasional;

h. memajukan perekonomian masyarakat Desa serta mengatasi kesenjangan pembangunan nasional;

i. memperkuat masyarakat Desa sebagai subjek pembangunan.

Dengan menjadikan mediasi sebagai perangkat yang dikenal dan digunakan di desa/kelurahan, maka akan dapat mewujudkan amanat penataan desa sebagaimana tercantum dalam pasal 7 ayat 3 Undang-undang Desa, yaitu :

a. mewujudkan efektivitas penyelenggaraan Pemerintahan Desa;

b. mempercepat peningkatan kesejahteraan masyarakat Desa;

c. mempercepat peningkatan kualitas pelayanan publik;

d. meningkatkan kualitas tata kelola Pemerintahan Desa; dan

e. meningkatkan daya saing Desa. $^{6}$

\footnotetext{
${ }^{6}$ Sekretariat Negara RI, Undang-Undang Republik Indonesia No: 6 Tahun 2014 Tentang Desa.
}

Berdasarkan latar belakang di atas maka tulisan berikut menelaah apakah urgensi dan manfaat menjadikan desa sebagai basis sosialisasi dan pelatihan mediasi?

\section{B. Metode Penelitian}

Penelitian berikut ini adalah penelitian hukum sosiologis tentang efektivitas Mediasi dengan menjadikan desa sebagai basis pelaksanaan mediasi untuk penyelesaian sengketa.

Ditinjau dari sifatnya, penelitian ini adalah penelitian eksploratif, yang bertujuan untuk memperdalam pengetahuan mengenai suatu gejala tertentu atau untuk mendapatkan ide-ide baru mengenai suatu gejala itu. Dari sudut bentuknya adalah penelitian perspektif yang dimaksudkan untuk mendapatkan saran-saran mengenai apa yang harus dilakukan untuk mengatasi masalah tertentu. Tujuannya adalah fact finding (menemukan fakta), lalu problem finding, menuju problem identification, problem solutions. ${ }^{7}$

Data primer berasal dari data yang diperoleh dari sumber pertama diperoleh dari kuesioner. Data sekunder mencakup dokumendokumen resmi, buku-buku, hasil penelitian yang berwujud laporan dan sebagainya. ${ }^{8}$

\section{PEMBAHASAN}

\section{A. Urgensi Mediasi Di Desa}

Pelatihan dan penggunaan mediasi sebagai alternatif penyelesaian sengketa perdata di

${ }^{7}$ Zainal Asikin and Amiruddin, Pengantar Metode Penelitian Hukum, 9th ed. (Raja Grafindo Persada, 2016).

${ }^{8}$ Zainal Asikin and Amiruddin, Pengantar Metode Penelitian Hukum, 9th ed. (Jakarta: Raja Grafindo Persada, 2016). 
tingkat desa bisa memperkuat tujuan pengaturan desa sebagaimana tercantum dalam Pasal 4 UU tentang Desa.

\section{Konflik/sengketa}

dilatarbelakangi oleh perbedaan ciriciri yang dibawa individu dalam berinteraksi. Perbedaan tersebut menyangkut ciri fisik, kepandaian, pengetahuan, adat istiadat, keyakinan, dan lain-lain. Dengan dibawa sertanya ciri-ciri individual dalam interaksi sosial, konflik merupakan situasi yang wajar dalam setiap masyarakat dan tidak satu masyarakat pun yang tidak pernah mengalami konflik antar anggotanya atau dengan kelompok masyarakat lainnya. Konflik akan hilang bersama hilangnya masyarakat. ${ }^{9}$

Johan Galtung menerangkan siklus konflik sebagai berikut: Konflik memiliki siklus hidupnya sendiri; seperti sesuatu yang organik 'makhluk hidup". Konflik nampak, mencapai klimaks emosional, bahkan kekerasan, kemudian berangsur-angsur berkurang, menghilang lalu muncul kembali. Siklus konflik adalah sebagai berikut: ${ }^{10}$

1. Perbedaan tujuan, tidak sama satu sama lain, seperti dua negara yang menginginkan tanah yang sama, atau dua negara yang menginginkan negara yang sama;

2. Ketika tujuan tidak sesuai/berbeda, muncullah kontradiksi, lalu masalah lahir;

${ }^{9}$ A. Rusdiana, Manajemen Konflik, 1st ed. (Bandung: Pustaka Setia, 2015).

10 Johan Galtung, Conflict Transformation by Peaceful Means (the Transcend Method), United Nations DMTP (United Nation Disaster Management Training Programme (DMTM), 2000),

https://www.transcend.org/pctrcluj2004/TRANSC END_manual.pdf.
3. Para pihak/aktor karena keinginannya yang tidak terealisasi merasa frustrasi dan merasa itulah tujuan mendasar, seperti kebutuhan dasar dan kepentingan dasar;

4. Frustrasi dapat menyebabkan agresi, berubah ke dalam sebagai sikap kebencian, atau keluar sebagai perilaku kekerasan verbal atau fisik;

5. Kebencian dan kekerasan dapat diarahkan kepada tujuan/niat awal, tetapi tidak selalu dapat menerima;

6. Kekerasan dimaksudkan untuk membahayakan dan menyakiti (termasuk dirinya sendiri), dan dapat melahirkan spiral kontrakekerasan sebagai pertahanan atau balas dendam;

7. Bahwa spiral/putaran kebencian dan kekerasan dapat menjadi sebuah meta-konflik, dengan tujuan melestarikan dan menghancurkan.

Spiral konflik dapat muncul di mana saja termasuk di desa. Dengan menjadikan desa sebagai basis mediasi diharapkan dapat mengurangi jumlah konflik yang masuk ke pengadilan, memberdayakan masyarakat desa dan melatih masyarakat untuk menyelesaikan permasalahan dan konflik secara damai.

Tujuan pengenalan mediasi di desa adalah untuk memberi pemahaman kepada pemerintahan desa bahwa penyelesaian/transformasi konflik ini adalah melalui jalan perdamaian, mendorong kemampuan menyelesaikan konflik secara kreatif dan tanpa kekerasan. Dengan 
harapan dan visi dari hasil perdamaian yang berkelanjutan yang diterima oleh semua pihak bisa jadi akan mengubah konflik jauh sebelum ada kesepakatan. Tujuannya bukan untuk solusi final, tetapi untuk mengubah konflik dan membangun kapasitas bagi para pihak sendiri untuk menangani konflik tanpa kekerasan dan secara kreatif. ${ }^{11}$

\section{B. Mediasi Sarana Penyelesaian Sengketa Yang Efektif}

Mediasi merupakan cara penyelesaian sengketa secara damai yang tepat, efektif, dan dapat membuka akses yang lebih luas kepada Para Pihak untuk memperoleh penyelesaian yang memuaskan serta berkeadilan. Mediasi dapat menjadi instrumen untuk meningkatkan akses masyarakat terhadap keadilan sekaligus implementasi asas penyelenggaraan peradilan yang sederhana, cepat, dan berbiaya ringan. Mendorong Para Pihak untuk menempuh proses perdamaian yang dapat didayagunakan melalui Mediasi. $^{12}$

Bryan A Garner mendefiniskan mediasi sebagai " $a$ methode of nonbinding dispute resolution involving a neutral third

11 Ibid. The goal of conflict transformation is peace; the capacity to handle conflict creatively and nonviolently. Visions of a sustainable outcome acceptable to all parties may transform the conflict long before any agreement. The goal is not any final solution, but to transform the conflict and build the capacity for the parties themselves to handle conflicts nonviolently and creatively.

12 PERMA, Peraturan Mahkamah Agung Republik Indonesia Nomor 1 Tahun 2016 Tentang Prosedur Mediasi Di Pengadilan, 2016. party who tries to help the disputing parties reach a mutually agreeable solutions" (suatu metode penyelesaian sengketa yang tidak mengikat, melibatkan pihak ketiga netral yang berusaha untuk membantu pihak-pihak yang bersengketa untuk mencapai solusi yang disepakati yang saling menguntungkan). ${ }^{13}$

Pasal 1 ayat 1 Perma No 1 tahun 2016 menyatakan mediasi adalah cara penyelesaian sengketa melalui proses perundingan untuk memperoleh kesepakatan Para Pihak dengan dibantu oleh Mediator.

Masyarakat desa perlu mendapatkan pengetahuan tentang alternatif penyelesaian konflik menggunakan mediasi, yang sangat berbeda model penyelesaian sengketa dengan pengadilan yang lambat, biaya perkara mahal, putusan tidak menyelesaikan masalah, putusan pengadilan membingungkan, tidak memberi kepastian hukum dan kemampuan hakim yang bersifat generalis. ${ }^{14}$

Penyelesaian sengketa di luar pengadilan dengan mediasi lebih memberdayakan dan menguntungkan bagi masyarakat desa, yaitu: ${ }^{15}$

\section{a. Penyelesaian bersifat}

informal. Prosedur dan acara penyelesaian lebih fleksibel sesuai dengan kesepakatan para

${ }^{13}$ Bryan A Garner, Black's Law Dictionary, ed. Bryan A Garner, 7th ed. (ST. Paul Minn: West Publishing Co, 2000).

${ }^{14}$ M Yahya Harahap, Hukum Acara Perdata Tentang Gugatan, Persidangan, Penyitaan, Pembuktian Dan Putusan Pengadilan, 2nd ed. (Jakarta: Sinar Grafika, 2017).

15 Komariah, "Analisis Yuridis PERMA No.1 Tahun 2008 Tentang Pelaksanaan Mediasi Di Pengadilan Sebagai Faktor Yang Mempengaruhi Efektifitas Proses Mediasi Di Pengadilan Negeri," Legality; Jurnal Ilmiah Hukum, no. 1 (2008): 3151. 
pihak. Tentu saja ini sangat sesuai dengan kultur masyarakat pedesaan yang sederhana dan menghindari hal-hal yang rumit.

b. Yang menyelesaikan sengketa para pihak sendiri. Penyelesaian tidak diserahkan kepada kemauan dan kehendak orang lain, tetapi diselesaikan oleh para pihak/anggota masyarakat sendiri sesuai dengan kemauan mereka. Hal ini tentu sangat membantu pemberdayaan masyarakat desa, karena dalam prosedur mediasi mereka adalah subyek dari proses penyelesaian sengketa. Dengan pemahaman yang komprehensif dari pemerintah desa terhadap mediasi akan sangat membantu pemberdayaan pemerintahan desa sekaligus masyarakatnya.

c. Jangka waktu penyelesaian singkat atau pendek. Jangka waktu penyelesaian dengan perdamaian dalam mediasi dapat dilakukan dengan singkat. Bila ada kemauan, ketulusan dan kerendahan hati dari kedua belah pihak. Dalam iklim masyarakat desa yang tidak ingin berkonflik dan menghindari konflik, penggunaan mediasi akan sangat membantu mereka dalam penyelesaian sengketa secara cepat.

d. Biaya yang ringan. Biaya ringan karena proses penyelesaiannya singkat, dibantu oleh pemerintah desa yang mengenal dekat mereka sosial ekonomi masyarakat, dalam proses penyelesaian mediasi bisa jadi tanpa mengeluarkan biaya sama sekali (zero cost).

e. Aturan pembuktian tidak diperlukan. Yang dibutuhkan adalah kejujuran, ketulusan dan keinginan untuk menyelesaikan permasalahan yang ada. Anggota masyarakat yang bersengketa tidak saling berbantahan, berargumentasi, mematahkan pernyataan pihak lawan melalui alat-alat bukti seperti sistem peradilan.

f. Proses penyelesaian bersifat rahasia. Dengan pelatihan dan pelembagaan di desa, pemerintah desa diajarkan untuk menjaga rahasia para pihak yang bersengketa. Memusnahkan catatan selama proses mediasi dan tidak menceritakannya kepada pihak lain.

g. Hubungan para pihak bersifat kooperatif. Dalam mediasi para pihak didorong untuk penyelesaian perkara berdasarkan kekeluargaan, musyawarah, kerja sama dan menganjurkan para pihak untuk tidak saling bermusuhan, menjauhkan diri dari sifat antagonisme, egoisme rasa dendam satu sama lain.

h. Menjaga Komunikasi dan fokus pada penyelesaian. Dalam penyelesaian mediasi, para pihak didorong agar bisa terus berkomunikasi secara aktif secara dua arah antara para pihak. Di dalam komunikasi masing-masing Pihak didorong untuk memperbaiki perselisihan dan kesalahan masa lalu menuju hubungan yang lebih baik untuk masa depan. 
i. Hasil yang dituju sama-sama menang atau win-win solution. Hasil yang diinginkan dalam penyelesaian mediasi adalah sama-sama menang atau winwin solution. Para pihak dipahamkan bahwa mereka tidak ada yang dikalahkan, semua sama-sama menang, sama sama lega dengan adanya penyelesaian sengketa sedangkan hubungan baik antara pihak masih tetap terjaga.

j. Bebas emosi dan dendam. Penyelesaian sengketa melalui mediasi meredam sikap emosional, fokusnya kepada penyelesaian sengketa dengan tetap menjaga hubungan baik di antara para pihak.

Tidak sedikit masyarakat di desa yang menyelesaikan masalahnya dengan menggunakan mediasi. Namun dengan istilah lain seperti musyawarah. Bermusyawarah dipimpin oleh kepala desa, seseorang yang dituakan atau yang ditunjuk oleh kepala desa. Tetapi secara kriteria model penyelesaiannya seperti mediasi yaitu: metode penyelesaian sengketa yang tidak mengikat, melibatkan pihak ketiga netral yang berusaha untuk membantu pihakpihak yang bersengketa untuk mencapai solusi yang disepakati yang saling menguntungkan.

Efektivitas musyawarah sebagai pengganti istilah mediasi di desa sebagai penyelesaian sengketa diakui oleh aparat desa yang menjadi responden sangat efektif dalam membantu penyelesaian perkara di desa.

Dari 91 kuesioner yang disebar ke aparat desa sekitar 63 (70\%) responden asal Cirebon, 8 (9\%) responden dari kuningan, 5
$(5 \%)$ responden Majalengka, 8 (9\%0 responden asal Indramayu, $1(1 \%)$ responden asal Brebes dan $6(6 \%)$ orang responden dari Tegal.

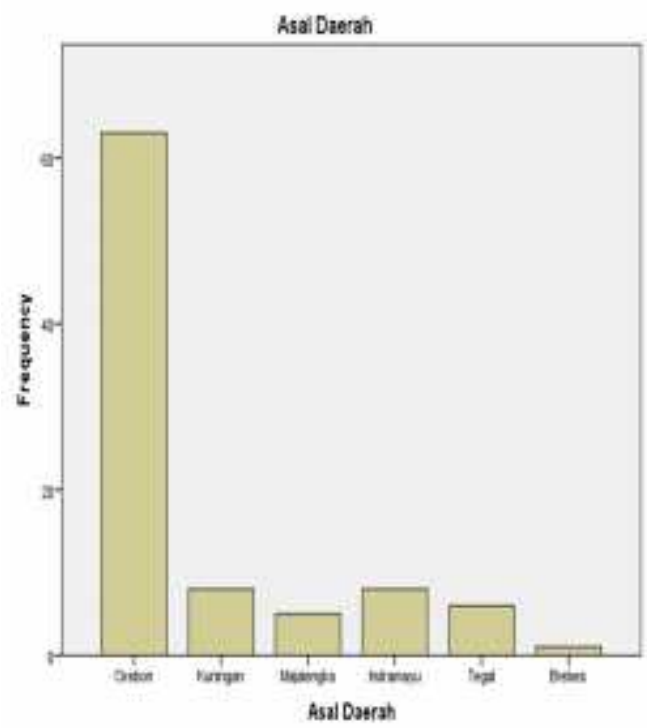

Kasus yang masuk perbulan, tidak menjawab 12 responden (13\%), diatas 5 kasus perbulan 69 responden (76\%) dan yang menjawab diatas 5 kasus perbulan 10 responden $(11 \%)$.

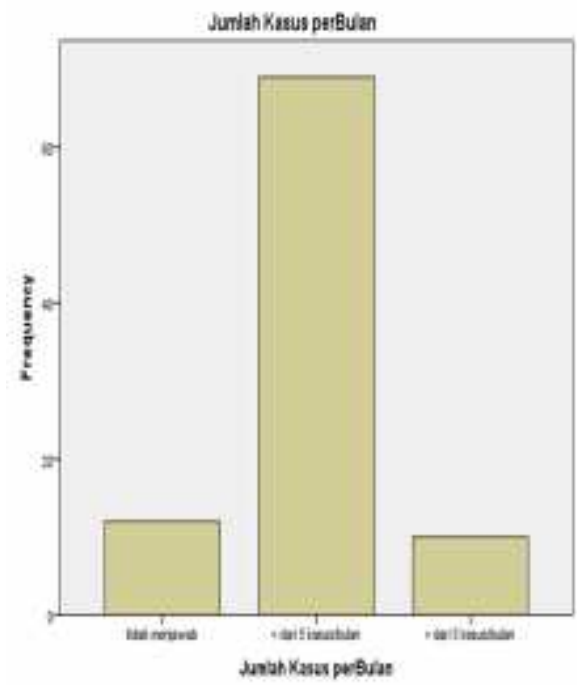

Saat ditanyakan tentang apakah aparat desa pernah belajar mediasi, 17 orang (19\%) responden menjawab belajar mediasi, 66 responden $(73 \%)$ menjawab tidak belajar mediasi dan $8(9 \%)$ tidak menjawab. 


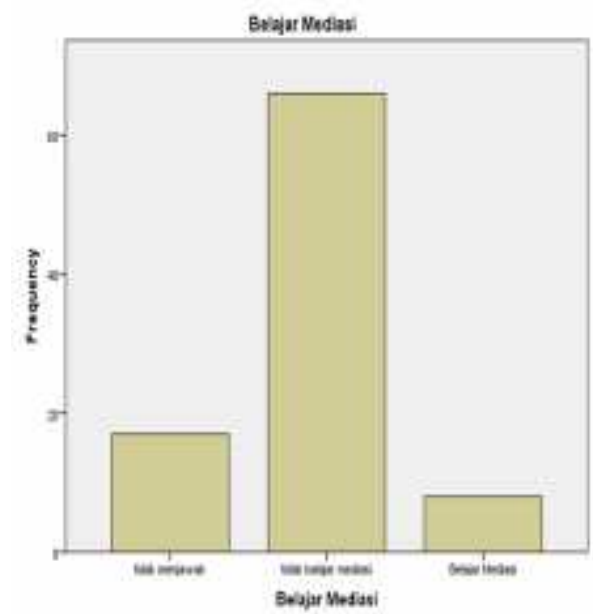

Dilihat dari tingkat keberhasilan penyelesaian sengketa, mediasi sangat berhasil 45 (50\%) Responden, mediasi cukup berhasil $28(30 \%)$ responden, tidak berhasil 6 (7\%), tidak menjawab 12 (13\%).

Secara keseluruhan dari data kuantitatif diatas dapat diambil beberapa poin yaitu, Rata-rata kasus yang diselesaikan di desa kurang dari 5/bulan (76\%), sebagian besar tanpa belajar mediasi (72\%), namun dengan harapan yang sangat besar bahwa mediasi cukup berhasil dan sangat berhasil sebesar $80 \%$.

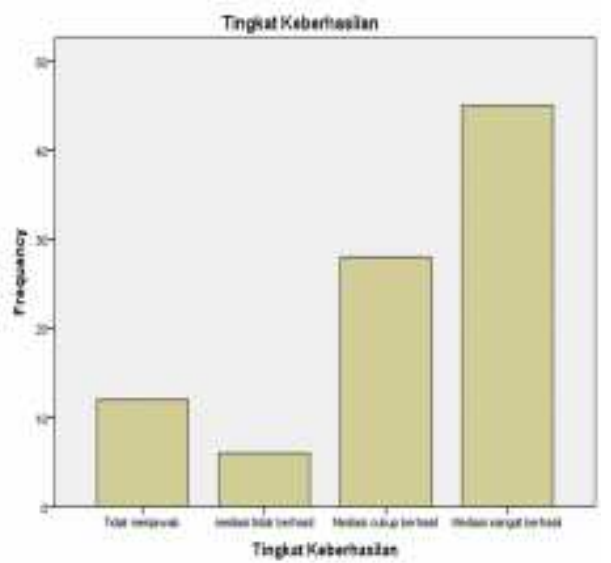

\section{Tingkat Pendidikan Masih Rendah dan Kemiskinan tinggi}

Potret Pendidikan Indonesia dalam Statistik Pendidikan 2017 tercatat beberapa tantangan pendidikan di Indonesia ke depannya. Akses internet yang tinggi dan partisipasi di media sosial yang semakin tinggi, semakin tinggi jenjang pendidikan semakin banyak siswa putus sekolah. ${ }^{16}$

Masih terdapat penduduk yang tidak/belum pernah bersekolah pada rentang umur 7-24 tahun. Meskipun angkanya relatif kecil, artinya pada kelompok umur 7-12 tahun masih terdapat penduduk yang sudah tidak bersekolah lagi. Angka tersebut meningkat seiring pertambahan umur. Angka terbesar yaitu pada kelompok umur 16-18 dan 19-24 tahun. Kelompok umur tersebut adalah kelompok umur yang bersesuaian dengan jenjang pendidikan SMA/sederajat dan perguruan tinggi. Dengan demikian, dapat dikatakan bahwa penduduk umur 5-24 tahun cenderung putus sekolah pada jenjang SMA/sederajat dan tidak melanjutkan pendidikan ke jenjang perguruan tinggi. ${ }^{17}$

\section{Padahal}

Pendidikan

berkualitas merupakan jalur yang mampu menciptakan manusia unggul, berkualitas, dan berdaya saing yang kelak menjadi generasi tumpuan harapan bangsa, engine of growth, dan lokomotif pembangunan. Di sinilah peran penduduk umur sekolah 7-24 tahun diperlukan karena mereka masuk menjadi bagian dari komposisi penduduk yang akan memanfaatkan peluang tersebut, mengingat umur 7-24 tahun merupakan rentang umur sekolah, di mana hendaknya mereka yang berada pada rentang umur tersebut masih aktif dalam

\footnotetext{
16 Badan Pusat Statistik, Potret Pendidikan Indonesia; Statistik Pendidikan 2017 (Jakarta: Badan Pusat Statistik, 2017).

17 Badan Pusat Statistik, Potret Pendidikan Indonesia; Statistik Pendidikan 2017
} 
mengenyam pendidikan di bangku sekolah tanpa terkecuali. ${ }^{18}$

Tingginya angka putus sekolah pada jenjang pendidikan menengah ke atas masih menjadi kendala. Pemerintah perlu mengupayakan agar anak-anak di Indonesia bisa mengenyam pendidikan minimal sampai tingkat menengah ke atas. angka putus sekolah di perdesaan lebih besar dibandingkan di perkotaan. Selisih angka perkotaan dan perdesaan semakin besar seiring meningkatnya jenjang pendidikan. Semakin tinggi jenjang pendidikan semakin banyak angka putus sekolah.

Beracara di pengadilan membutuhkan pengetahuan tentang hukum dan beracara yang memadai, sementara proyeksi angka putus sekolah yang semakin membesar di tingkat SMA/SMK, sehingga tersirat sebetulnya masyarakat akan sangat terbantu dengan keberadaan mediasi di tingkat desa.

Berdasarkan data BPS September 2017, jumlah penduduk miskin yang tinggal di Kota 10,27 juta $(7,26 \%)$, sedangkan desa adalah 16,31 juta $(13,47 \%)$ total 26,58 juta dalam kemiskinan. Dengan pendapatan perkapita penduduk kota Rp 400.995,- dan penduduk desa Rp. $370.910,-{ }^{19}$

18 Badan Pusat Statistik, Potret Pendidikan Indonesia; Statistik Pendidikan 2017.

${ }^{19}$ Badan Pusat Statistik, Jumlah Penduduk Miskin, Persentase Penduduk Miskin Dan Garis Kemiskinan, 1970-2017 (Jakarta, 2018), https://www.bps.go.id/statictable/2014/01/30/1494/ jumlah-penduduk-miskin--persentase-pendudukmiskin-dan-garis-kemiskinan--1970-2017.html.

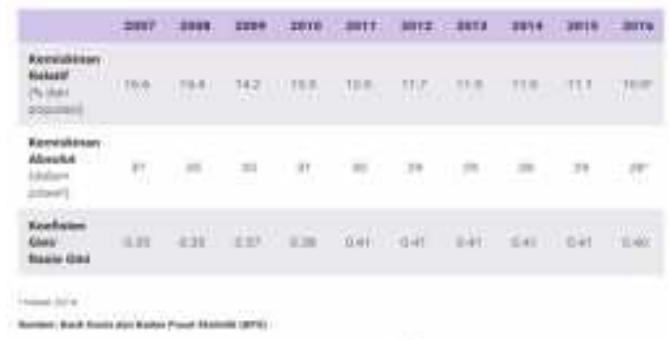

Sumber tabel: ${ }^{20}$

Tabel di atas menunjukkan penurunan kemiskinan nasional secara perlahan dan konsisten. Namun, pemerintah tidak menggunakan persyaratan yang ketat mengenai definisi garis kemiskinan, sehingga yang tampak adalah gambaran yang lebih positif dari kenyataannya. Tahun 2016 pemerintah Indonesia mendefinisikan garis kemiskinan dengan perdapatan per bulannya (per kapita) sebanyak Rp. 354,386 (atau sekitar USD \$25) yang dengan demikian berarti standar hidup yang sangat rendah, juga buat pengertian orang Indonesia sendiri. ${ }^{21}$

Jika menggunakan nilai garis kemiskinan yang digunakan Bank Dunia, yang mengklasifikasikan persentase penduduk Indonesia yang hidup dengan penghasilan kurang dari USD \$1.25 per hari sebagai mereka yang hidup di bawah garis kemiskinan (dengan kata lain miskin), maka persentase tabel di atas akan kelihatan tidak akurat karena nilainya seperti dinaikkan beberapa persen. Lebih lanjut lagi,

20 https://www.indonesiainvestments.com/id/keuangan/angka-ekonomimakro/kemiskinan/item301? 2

https://www.indonesiainvestments.com/id/keuangan/angka-ekonomimakro/kemiskinan/item301?.

Rasio Gini (atau koefisien), yang mengukur ketimpangan distribusi pendapatan, merupakan indikator penting untuk menilai tingkat 'kebenaran' di suatu negara (meskipun indikator ini memang memiliki beberapa kekurangan). Koefisien Gini 0 menunjukkan kesetaraan sempurna, sementara koefisien 1 menunjukkan ketidaksetaraan sempurna. 
menurut Bank Dunia, kalau kita menghitung angka penduduk Indonesia yang hidup dengan penghasilan kurang dari USD \$2 per hari angkanya akan meningkat lebih tajam lagi. Ini menunjukkan bahwa sebagian besar penduduk Indonesia hidup hampir di bawah garis kemiskinan. Laporan lebih anyar lagi di media di Indonesia menginformasikan bahwa sekitar seperempat jumlah penduduk Indonesia (sekitar 65 juta jiwa) hidup hanya sedikit saja di atas garis kemiskinan nasional. ${ }^{22}$

Untuk berperkara di pengadilan, pada asasnya dikenakan biaya yang tidak sedikit. ${ }^{23}$ Walaupun bagi yang tidak mampu ada perkara secara cuma-cuma (gratis) namun, seperti terjadi di Pengadilan agama Pamekasan anggaran yang disiapkan oleh negara dalam anggaran DIPA pengadilan agama Pamekasan tidaklah memadai sehingga setiap tahunnya hanyalah $30(30 \%)$ perkara dari 100 perkara saja yang tentu saja tidak sebanding dengan jumlah perkara yang diputus oleh pengadilan agama. ${ }^{24}$

Walaupun tidak ada hambatan lagi dalam masalah utama keuangan karena bebas biaya perkara namun akses masyarakat miskin ke pengadilan masih mengalami kesulitan. Masalah tersebut adalah masalah pendidikan yang tidak memadai, ongkos transportasi untuk datang ke pengadilan dan terutama kurangnya akses pengetahuan dan sosialisasi kepada masyarakat bahwa

\footnotetext{
$22 \quad$ Ibi https://www.indonesiainvestments.com/id/keuangan/angka-ekonomimakro/kemiskinan/item301?d.

${ }^{23}$ Sudikno Mertokusumo, Hukum Acara Perdata Indonesia, Revisi. (Yogyakarta: Cahaya Atma Pustaka, 2013).

${ }^{24}$ Eka Susylawati, "Implementasi Perkara Gratis Bagi Masyarakat Miskin Di Pengadilan Agama Pamekasan," Nuansa 10, no. 1 (2013).
}

di pengadilan sudah dianggarkan untuk berperkara secara gratis. ${ }^{25}$

Yang memperoleh perkara gratis biasanya orang yang dekat, mereka yang terbiasa dan mengetahui seluk beluk di pengadilan. Umumnya masyarakat yang mengetahui bahwa di pengadilan agama ada perkara gratis dari kepala desa, modin atau petugas KUA. Atau bisa juga ada staff di pengadilan agama yang menginformasikannya secara langsung kepada orang yang mendaftarkan perkaranya secara gratis.

Akumulasi tingkat pendidikan yang masih relatif rendah dan angka kemiskinan yang cenderung tinggi mengakibatkan orang dalam kubangan kemiskinan dan kebodohan akan menghindari pengadilan untuk penyelesaian sengketa, pasrah dengan permasalahan dan konflik yang dihadapi. Dengan demikian maka mediasi sebagai metode penyelesaian sengketa yang murah, cepat, efektif dan efisien perlu disosialisasikan, diajarkan dan diterapkan oleh pemerintahan desa.

\section{Secara Demografi Penduduk Indonesia terus meningkat perkara yang masuk ke pengadilan semakin bertambah.}

Proyeksi penduduk Indonesia menunjukkan bahwa jumlah penduduk Indonesia selama dua puluh lima tahun mendatang terus meningkat yaitu dari 238,5 juta pada tahun 2010 menjadi 305,6 juta pada tahun 2035. Walaupun demikian, pertumbuhan rata-rata per tahun penduduk Indonesia selama periode 2010-2035 menunjukkan

25 Eka Susylawati, "Implementasi Perkara Gratis Bagi Masyarakat Miskin Di Pengadilan Agama Pamekasan," 
kecenderungan terus menurun. Dalam periode 2010-2015 dan 20302035 laju pertumbuhan penduduk turun dari 1,38 persen menjadi 0,62 persen per tahun. Turunnya laju pertumbuhan ini ditentukan oleh turunnya tingkat kelahiran dan kematian. Tingkat penurunan karena kelahiran lebih cepat daripada tingkat penurunan karena kematian. Angka Kelahiran Kasar (Crude Birth Rate/CBR) turun dari sekitar 21,0 per 1000 penduduk pada awal proyeksi menjadi 14,0 per 1000 penduduk pada akhir periode proyeksi, sedangkan Angka Kematian Kasar (Crude Dead Rate/CDR) naik dari 6,4 per 1000 penduduk menjadi 8,8 per 1000 penduduk dalam kurun waktu yang sama. $^{26}$

Proyeksi pertambahan penduduk Indonesia ke depan berarti seiring dengan pertambahan penduduk maka semakin banyak lapangan pekerjaan yang dibutuhkan, penyediaan pendidikan semakin bertambah, potensi konflik ke depan juga semakin bertambah.

Laporan Tahunan Mahkamah Agung Republik Indonesia (LTMARI) tahun 2016 mencatat kenaikan jumlah kasus di semua peradilan dari tahun 2015 ke 2016, Kenaikan Perkara Perdata Di Pengadilan Tingkat Pertama Tahun 2014, 2015 dan 2016 Kenaikan Gugatan dan Permohonan Pada Pengadilan Agama Tahun 2014, 2015 dan 2016.

26 Badan Pusat Statistik Indonesia, Proyeksi Penduduk Indonesia, Indonesia Population Projection 2010-2035, Badan Pusat Statistik Indonesia, 2013.

1. Kenaikan Jumlah Perkara Semua Peradilan Tahun 2015 Hingga 2016

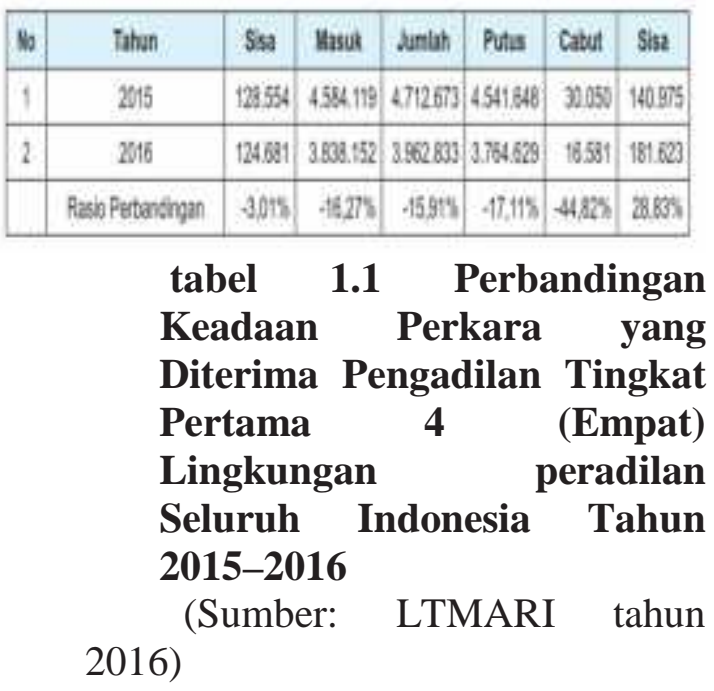

Jumlah perkara yang diterima tahun 2015 adalah 4.556 .580 perkara, sisa tahun 2014 sebanyak 128.554 perkara sehingga masuk 4.712.673. dibanding dengan tahun 2015 ke tahun 2015 Jumlah perkara yang diterima tahun 2016 menurun $15,91 \%$ dibandingkan penerimaan tahun 2015 sebanyak. Jumlah perkara putus menurun $17,11 \%$ dari tahun 2015 yang berjumlah 4.541.648 perkara. Rasio jumlah perkara putus dibandingkan dengan beban perkara sebesar 95\%. Rasio sisa perkara dibandingkan dengan beban perkara sebesar $4,58 \%$. (lihat tabel 1.0)

Banyaknya kasus yang ditangani oleh Pengadilan tingkat pertama di seluruh Indonesia tahun 2016 sebanyak 3.838.152 perkara, sisa perkara tahun 2015 sebanyak 124.621 perkara, total perkara yang diadili berjumlah 3.962.833 perkara. Perkara yang telah diputus sebanyak 3.764.629 perkara dan dicabut sebanyak 16.581 perkara. Sisa 
perkara pada akhir tahun sebanyak 181.623 perkara. $^{27}$

\section{Kenaikan Perkara Perdata Di Pengadilan Tingkat Pertama Tahun 2014, 2015 dan 2016}

\begin{tabular}{|c|c|c|c|c|c|c|c|}
\hline $\mathrm{No}$ & Jenis Perban & $\begin{array}{l}\text { \$51 } \\
\text { 215 }\end{array}$ & Uasik & Beban & Pidas & Casut & Sisa \\
\hline 1 & Pendata Gigian & 11.152 & 30.741 & 41.685: & 23933 & 4043 & 13917 \\
\hline 2 & Pentra Pemotonan & 1330 & 39.981 & 41.291 & 3000 & 2000 & 3081 \\
\hline 3 & Qugaten Sodutusas & 5 & 754 & 75 & 630 & 0 & 12 \\
\hline & Junah & 12487 & 71,458 & 83543 & 59983 & 6.843 & $1210 ?$ \\
\hline
\end{tabular}

tabel 1.2 Perkara Perdata yang Diadili Pengadilan Negeri Tahun 2016 2016)

(sumber: LTMARI tahun

Perkara yang telah diputus pada tahun 2015 sebanyak 56.885 perkara. Sisa perkara pada akhir Desember 2015 sebanyak 15.123 perkara. Jumlah perkara perdata yang diterima pengadilan negeri tahun 2015 meningkat 14,90\% dibandingkan penerimaan tahun 2014 sebanyak 52.123 perkara. Perkara gugatan meningkat $7,35 \%$ dan perkara permohonan meningkat $22,67 \%$.

Perkara perdata yang diadili pengadilan negeri di seluruh Indonesia pada tahun 2016 sebanyak 83.943 perkara. Jumlah ini terdiri dari 71.456 perkara yang diterima tahun 2016 dan sisa perkara tahun 2015 sebanyak 12.487 perkara. Perkara perdata yang diadili tahun 2016 terdiri dari 41.893 perkara gugatan $(49,91 \%)$, sebanyak 41.291 perkara permohonan $(49,19 \%)$, dan sebanyak $759 \quad(0,90 \%)$ adalah perkara gugatan sederhana.

Jumlah perkara perdata yang diterima pengadilan negeri tahun

27 Pokja Laporan Tahunan MARI, Laporan Tahunan Mahkamah Agung Republik Indonesia Tahun 2016 (Jakarta, 2017).
$2016 \quad$ meningkat $19,31 \%$ dibandingkan penerimaan tahun 2015 sebanyak 59.890 perkara. Perkara gugatan meningkat $8,34 \%$ dan perkara permohonan meningkat $26,80 \%$. $^{28}$

Peningkatan perkara perdata tahun 2014 ke 2015 adalah 14,90\%, sedangkan di tahun 2015 terjadi peningkatan sebesar 19,31\%. Di sini kita melihat adanya peningkatan jumlah perkara yang ditangani oleh Peradilan perdata dari dua tahun terakhir.

3. Kenaikan Gugatan dan Permohonan Pada Pengadilan Agama Tahun 2014, 2015 dan 2016

\begin{tabular}{|c|c|c|c|c|c|c|c|}
\hline $\mathbb{k}$ & bis perkan & $\begin{array}{l}\text { S61 } \\
215\end{array}$ & Haut & $\begin{array}{l}\text { Jumlah } \\
\text { Beban }\end{array}$ & Patus & Cibut & Sist \\
\hline 1 & Qupalar & Q K5: & th:87? & 401,194 & 330391 & 8355 & 121268 \\
\hline \multirow[t]{2}{*}{2} & Pentecren & 4207 & 94233 & 5850 & 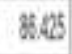 & 1014 & 11.601 \\
\hline & Jutht & $0 / 2$ & 50:10 & 요요 & $42,4 \%$ & 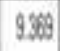 & 133.119 \\
\hline
\end{tabular}

Tabel 1.3 Perkara Gugatan dan Permohonan pada Pengadilan Agama Tahun 2016 2016)

(sumber: LTMARI tahun

Beban perkara Pengadilan Agama/Mahkamah Syar'iyah pada tahun 2015 sebanyak 559.975 perkara. Jumlah ini terdiri dari perkara masuk tahun 2015 sebanyak 481.413 perkara dan sisa tahun 2014 sebanyak 78.558 perkara. Perkara yang telah diputus sebanyak 451.262 perkara dan dicabut oleh para pihak sebanyak 30.009 perkara. Sisa perkara pada akhir tahun 2015 sebanyak 78.704 perkara.

28 Pokja Laporan Tahunan MARI, Laporan Tahunan Mahkamah Agung Republik Indonesia Tahun 2016. 
Jumlah perkara yang diterima tahun 2015 ini meningkat 5,89\% dari tahun 2014 yang menerima sebanyak 454.547 perkara. Perkara yang diputus juga meningkat 5,07\% dari tahun 2014 yang berjumlah 429.362 perkara. Rasio jumlah perkara yang diputus dibandingkan dengan jumlah beban kerja adalah 80,59\% sedangkan jumlah rasio sisa perkara sebesar $14,05 \%{ }^{29}$

Beban perkara Pengadilan Agama/Mahkamah Syar'iyah pada tahun 2016 sebanyak 590.239 perkara. Jumlah ini terdiri dari perkara masuk tahun 2016 sebanyak 501.490 perkara dan sisa tahun 2015 sebanyak 88.749 perkara. Perkara yang telah diputus sebanyak 447.704 perkara dan dicabut oleh para pihak sebanyak 9.369 perkara. Sisa perkara pada akhir tahun 2016 sebanyak 133.166 perkara. Jumlah perkara yang diterima tahun 2016 ini meningkat $4,10 \%$ dari tahun 2015 yang menerima sebanyak 481.176 perkara. ${ }^{30}$

Jumlah perkara yang diterima oleh peradilan agama dari tahun 2014 ke tahun 2015 meningkat $5,89 \%$, sedangkan peningkatan jumlah perkara yang diterima oleh peradilan agama dari tahun $2016 \mathrm{ke}$ 2017 meningkat 4,10\%. Baik peradilan perdata maupun peradilan perdata setiap tahun sejak tahun 2015 terus terjadi peningkatan.

29 Pokja Laporan Tahunan MARI, Laporan Tahunan Mahkamah Agung Republik Indonesia Tahun 2015.

30 Pokja Laporan Tahunan MARI, Laporan Tahunan Mahkamah Agung Republik Indonesia Tahun 2016.

\section{Rincian Perkara Semua Lingkungan Peradilan Tingkat Pertama Tahun 2016}

Jumlah perkara yang masuk ke lingkungan peradilan umum tahun 2016 terdiri dari sisa perkara tahun 2015 sebanyak 35.028 perkara, perkara masuk tahun 2016 sebanyak 3.331.656 jumlah total 3.366.674.

Adapun jumlah perkara yang masuk ke lingkungan peradilan agama adalah 88.749 perkara sisa tahun 2015, perkara masuk tahun 2016; 501490 perkara, total perkara masuk tahun 2016 dari lingkungan peradilan perdata adalah 590.239 perkara. Jika dibuat persentase perkara yang masuk di lingkungan peradilan umum dibanding dengan peradilan agama adalah bahwa peradilan agama hanya sekitar $17,5 \%$ saja.

Perkara perdata yang ditangani pengadilan negeri di seluruh Indonesia pada tahun 2015 sebanyak 72.008 perkara. Jumlah ini terdiri dari 59.890 perkara yang diterima tahun 2015 dan sisa perkara tahun 2014 sebanyak 12.118 perkara. Jumlah tersebut terdiri dari 39.279 perkara gugatan $(54,55 \%)$ dan sebanyak $32.729 \quad$ perkara permohonan $(45,45 \%){ }^{31}$

\begin{tabular}{|c|c|c|c|c|c|c|c|}
\hline No & $\begin{array}{l}\text { Lingkingsn } \\
\text { Puradian }\end{array}$ & $\begin{array}{l}\text { Sist } \\
215\end{array}$ & Nasuit & Juniah & Putur & Cabut & Sist \\
\hline 1 & Unum & 35008 & 3331,46 & 330644 & 3812.131 & 7,160 & 47375 \\
\hline 2 & kgenta & 38749 & 501.490 & 590259 & 497.70 & 8286 & 130.106 \\
\hline 3 & Viter & 324 & 2694 & 3318 & 2827 & 4 & 47 \\
\hline \multirow[t]{2}{*}{4} & TW & 58: & 2020 & 2600 & 1987 & & 635 \\
\hline & Juriat & 12661 & $363 \% 152$ & 39028053 & 3764600 & 16.881 & 181623 \\
\hline
\end{tabular}

31 Pokja Laporan Tahunan MARI, Laporan Tahunan Mahkamah Agung Republik Indonesia Tahun 2015 (Jakarta, 2016). 
Tabel 1.4 Rincian Keadaan Perkara yang Diterima MasingMasing Lingkungan Peradilan Tingkat Pertama Seluruh Indonesia Tahun 2016 2016)

(Sumber: LTMARI tahun

\section{KESIMPULAN DAN SARAN}

Akumulasi tingkat pendidikan yang relatif rendah dan angka kemiskinan yang cenderung tinggi mengakibatkan orang dalam kubangan kemiskinan dan kebodohan akan menghindari pengadilan untuk penyelesaian sengketa, pasrah dengan permasalahan dan konflik yang dihadapi. Maka mediasi sebagai metode penyelesaian sengketa yang murah, cepat, efektif dan efisien perlu disosialisasikan, diajarkan dan diterapkan oleh pemerintahan desa.

Dengan menjadikan desa sebagai basis penyelesaian sengketa alternatif diharapkan desa dapat menjadi filter penjaga untuk mengurangi jumlah kasus yang masuk ke pengadilan, sehingga kasus yang akan masuk ke pengadilan benar-benar perkara perdata yang tidak bisa diselesaikan secara kekeluargaan.

Perlu pelembagaan mediasi di tingkat desa melalui instrumen Badan Permusyawaratan Desa yang melaksanakan fungsi mediasi yang anggotanya ditunjuk oleh pemerintah desa.

\section{REFERENSI}

A. Rusdiana. Manajemen Konflik. 1st ed. Bandung: Pustaka Setia, 2015.

Asikin, Zainal, and Amiruddin. Pengantar Metode Penelitian Hukum. 9th ed. Raja Grafindo
Persada, 2016.

Pengantar Metode Penelitian Hukum. 9th ed. Jakarta: Raja Grafindo Persada, 2016.

Badan Pusat Statistik. Potret Pendidikan Indonesia; Statistik Pendidikan 2017. Jakarta: Badan Pusat Statistik, 2017.

Badan Pusat Statistik Indonesia. Proyeksi Penduduk Indonesia, Indonesia Population Projection 20102035. Badan Pusat Statistik Indonesia, 2013.

Bryan A Garner. Black's Law Dictionary. Edited by Bryan A Garner. 7th ed. ST. Paul Minn: West Publishing Co, 2000.

Galtung, Johan. Conflict Transformation by Peaceful Means (the Transcend Method). United Nations DMTP. United Nation Disaster Management Training Programme (DMTM), 2000. https://www.transcend.org/pctrclu j2004/TRANSCEND_manual.pdf

Komariah. "Analisis Yuridis PERMA No.1 Tahun 2008 Tentang Pelaksanaan Mediasi Di Pengadilan Sebagai Faktor Yang Mempengaruhi Efektifitas Proses Mediasi Di Pengadilan Negeri." Legality; Jurnal Ilmiah Hukum, no. 1 (2008): 31-51.

M Yahya Harahap. Hukum Acara Perdata Tentang Gugatan, Persidangan, Penyitaan, Pembuktian Dan Putusan Pengadilan. 2nd ed. Jakarta: Sinar Grafika, 2017.

PERMA. Peraturan Mahkamah Agung Republik Indonesia Nomor 1 Tahun 2016 Tentang Prosedur Mediasi Di Pengadilan, 2016.

Pokja Laporan Tahunan MARI. Laporan Tahunan Mahkamah Agung Republik Indonesia Tahun 2015. Jakarta, 2016.

. Laporan Tahunan Mahkamah 
Agung Republik Indonesia Tahun 2016. Jakarta, 2017.

Sekretariat Negara RI. Undang-Undang Republik Indonesia No: 6 Tahun 2014 Tentang Desa, 2014. http://www.setneg.go.id/index.ph $\mathrm{p}$ ?lang=en\&option=com_perunda ngan \&id $=404095 \&$ task $=$ detail $\& \mathrm{c}$ atid=1\&Itemid=42\&tahun=2014.

Statistik, Badan Pusat. Jumlah Penduduk Miskin, Persentase Penduduk Miskin Dan Garis Kemiskinan, 1970-2017. Jakarta, 2018. https://www.bps.go.id/statictable/ 2014/01/30/1494/jumlahpenduduk-miskin--persentasependuduk-miskin-dan-gariskemiskinan--1970-2017.html.

Sudikno Mertokusumo. Hukum Acara Perdata Indonesia. Revisi. Yogyakarta: Cahaya Atma Pustaka, 2013.

Susylawati, Eka. "Implementasi Perkara Gratis Bagi Masyarakat Miskin Di Pengadilan Agama Pamekasan." Nuansa 10, no. 1 (2013).

"Kemiskinan Dan Kesenjangan Di Indonesia." Accessed April 10, 2018. https://www.indonesiainvestments.com/id/keuangan/ang ka-ekonomimakro/kemiskinan/item301?

"Web Page." Accessed March 20, 2018. http://nasional.republika.co.id/ber ita/nasional/daerah/16/02/06/o245 76219-179-juta-pendudukmiskin-indonesia-tinggal-di-desa.

"Web Page." Accessed March 27, 2018. http://www.kemendagri.go.id/ne ws/2016/08/15/mendagri-baru42088-desa-dan-kelurahandiketahui-klasifikasinya.

"Web Page." Accessed March 20, 2018. https://www.cnnindonesia.com/na sional/20151019122431-2085775/ketimpangan-tinggi-desaterancam-ditinggal-penduduk.

"Web Page." Accessed March 3, 2018. https://nasional.kompas.com/read /2012/08/23/21232065/

Hampir.54.Persen.Penduduk.Indo nesia.Tinggal.di.Kota. 